\title{
Cost Overruns and Failure inConstruction Projects
}

\author{
Anita Rauzana \\ Department of Civil Engineering, Syiah Kuala University, Jl. SyechAbdurRauf, Banda Aceh, Aceh Province, \\ Indonesia
}

\begin{abstract}
Construction projects are facing a greater number of uncertainties and more severe risks, which could cause much bigger losses than in the past,therefore, undertakeof identification the factors that influence the cost overruns are indispensable. Resources of construction projects including the man, money, methods, machines, materials, and the market, all of these resources need to be arranged so that the project resources can be used effectively and efficiently or optimally. The purpose of this study was to identify the factors that cause the cost overruns in construction projects. Based on the results of the identification of the factors that cause the cost overrun on the implementation of construction project obtained several factors: estimated costs $(X 1)$, implementation and working relationships (X2), and the project documents (X3).
\end{abstract}

Keywords: Cost overruns, project, construction, contractor, contingency cost.

\section{Introduction}

In the implementation of projects, often projects experiencing cost overruns. Therefore, the project financing is the primary consideration, as usually involves a large number and vulnerable to the risk of project failure. Therefore, the implementation of construction projects requires a good project management, which aims to avoid or minimize project risks that may occur, including the risk of cost overrun and delay in execution time. A project will be successful if in accordance with the cost or budget has been planned, on time, and within specifications.

Thus, a much-needed level of expertise, knowledge and experience that high in estimating the cost of the project until the project's cash flow management during the implementation stage, expertise in coordinating project resources, and project control are good so there is no cost overrun that could harm the contractor.

The ability to make accurate cost predictions is critical to successful project delivery. In an attempt to assess the likelihood of cost overruns and put in place mechanisms to reduce their impact, several techniques have been espoused (Jahren and Ashe 1990; Birnie and Yates 1991; Attala and Hegazy 2003; Flyvbjerg 2008; Bhargava et al. 2010). Despite the application of such techniques as well as the adoption of innovative organizational and managerial practices, cost overruns in projects remain a pervasive problem (Hester et al. 1991; Ibbs and Allen 1995; Love 2002; Bhargava et al. 2010). Cost overruns have been attributed to the occurrence of optimism bias or strategic misrepresentation during the formation of a project's budget (Flyvbjerg $2007 \mathrm{a}, \mathrm{b}$ ). Optimism bias is the demonstrated systematic tendency for people to be overly optimistic about the outcome of planned actions (Kahneman et al. 1982; Lovallo and Kahneman 2003). This includes overestimating the likelihood of positive events and underestimating the likelihood of negative events. Alternatively, strategic misrepresentation is the planned, systematic distortion or misstatement of fact; it is essentially lying (Jones and Euske 1991).

\section{Construction Project}

Construction activity is an integral part of a country's infrastructure and industrial development and must be taken care of for a healthy growth of the economy. It is imperative to put an all-out effort into ensuring that projects are completed as per the stipulated objectives. The completion of a project requires input from a variety of groups, including the client, the project team, the parent organization, the producer, and the end user. Each party has a role in defining and determining success. They all have specific tasks and responsibilities that they must fulfill to achieve success (Kumar 1989). A number of critical success factors (CSFs) affecting schedule and cost performance have been identified for the construction industry (Iyer and Jha 2005, 2006).

According to Ervianto (2004), the construction project is a series of activities carried out just once and short term nature. In a series of activities, there is a process of taking resources into a project activity results in the form of the building. Besides the construction project has three characteristics that are unique, requiring of resources (money, machines, methods, and materials), and requires the organization.

Suharto (2001) said that project management are planning, organizing, directing, and controlling the resources of the company to achieve short-term goals that have been determined. Goal of the project is composed of elements of cost, quality, and time. The third objective of the project is the triple constraint as follows: 
1. Cost, the project must be completed at a cost do not exceed the budget.

2. Quality, product or output of the project must meet the required specifications and criteria.

3. The time, the project must be done in accordance with the period and the end date specified.

\subsection{Estimated Budget}

Ibrahim (1995) stated that the Estimated Budget of a project is the calculation of the amount of the budget and wage costs of a building, as well as other costs associated with the implementation of the project. Budget in the same building will be different in each of regions, due to differences in prices of building materials and labor costs. Mentalini (2010) stated that the Budget Implementation Plan is a plan of the amount of the costs involved in the implementation of construction projects. Plan Project Budget planned and used as a guideline in order to expenditures not exceed the budget limits provided, but can achieve quality and job quality in accordance with the specifications stipulated in the contract.

\section{Causes of Cost Overrun}

Cost overrun is a condition in which the actual costs exceed the planned costs. In general, in the implementation of construction projects found many projects thatexperiencing cost overrun and delay in completion time. This can happen at the planning stage, as well as at the implementation stage, it is necessary to control / good control (Rizal, 1996).

The term cost overrun is often referred to as a budget increase, cost increase, or cost growth. A cost overrun should, however, be distinguished from cost escalation, which is used to express an anticipated growth in a budgeted cost due to factors such as inflation. A lack of a standard definition juxtaposed with the inappropriate distribution models has contributed to the formulation of inaccurate cost overrun probability forecasts. Nijkamp and Ubbels (1999), Flyvbjerg et al. (2002), and Odeck (2004), for example, defined a cost overrun as the difference between forecasted and actual construction costs.

Over the last few decades, there has been much research into the factors that affect cost performance in the construction phase of projects. Usually the vast majority of cost overruns occur during the construction phase, in which many unforeseen factors are conceived over the conception/design stages (Chan and Kumaraswamy 1997). Attributes such as poor site management and supervision, low speed of decision-making and client-initiated variations have reportedly been some of the most significant causes of cost overruns in the construction phase of projects (Trost and Oberlender 2003; Iyer and Jha 2005). The project manager couldcause cost overruns, as project management involves the management of resources such as labor, machinery, money, materials, and methods during this period (Frimpong et al. 2003). Identification of cost overruns factor is essential to the estimator andthe parties that concerned in the construction project.

\subsection{Causes of Cost Overrun}

Causes of the cost overruns in construction projects due to several factors, the description of the causes of cost overruns on previous research are as follows:

Table 1.1.Causes of Cost Overrun

\begin{tabular}{|l|l|l|}
\hline Variable & Indicator & Author \\
\hline Estimated costs & Incomplete data and information project & Fahirah (2005) \\
\cline { 2 - 3 } & Underestimates the effect of inflation and escalation & Fahirah (2005) \\
\cline { 2 - 3 } & Underestimates the contingency fee & Fahirah (2005) \\
\cline { 2 - 3 } & Lack of attention to risk of locations & Fahirah (2005) \\
\cline { 2 - 3 } & Inaccuracy of Work Breakdown Structure & Fahirah (2005) \\
\cline { 2 - 3 } Implementation & Inaccuracy of cost estimate & Fahirah (2005) \\
\cline { 2 - 3 } and working & Using the wrong estimation techniques & Fahirah (2005) \\
\cline { 2 - 3 } & The high frequency of change implementation & Fahirah (2005) \\
\cline { 2 - 3 } & Too many repetition of work due to poor quality & Fahirah (2005) \\
\cline { 2 - 3 } & The many projects are handled simultaneously & Fahirah (2005) \\
\cline { 2 - 3 } & Unfavorable telationship between the owner, planners, and contractors & Fahirah (2005) \\
\cline { 2 - 3 } & Lack of coordination between construction managers, planners and contractors & Fahirah (2005) \\
\cline { 2 - 3 } & There is a difference / dispute in the project & Fahirah (2005) \\
\cline { 2 - 3 } & The project manager is incompetent / proficient & Fahirah (2005) \\
\cline { 2 - 3 } & Consultants are less able in the project monitoring & Fahirah (2005) \\
\cline { 2 - 3 } & Environmental pollution due to project activities & Wattymury (2015) \\
\cline { 2 - 3 } & The conflict between the contractor and consultant & Wattymury (2015) \\
\hline \multirow{5}{*}{$\begin{array}{l}\text { The project } \\
\text { documents }\end{array}$} & The specificationis incomplete & Fahirah (2005) \\
\cline { 2 - 3 } & Design changes & Fahirah (2005) \\
\cline { 2 - 3 } & Contract documents are not complete & Fahirah (2005) \\
\hline
\end{tabular}




\subsection{Contingency Cost}

Latupeirissa (2007) stated that contingency cost is defined as the uncertainty of the cost of a cost estimate or budget to be allocated to the work item based on experience and implementation of projects in the past and is one of the integral part of the total estimated project cost.

Mak and Picken (2000) stated that contingency cost is the amount of funds providedas a backup to face the uncertainties relating to the construction project. Contingency costis particularly important when previous experiences related to costs indicate thatit is possibleto expectevents of unpredictable and lead to increased costs.

Contingency cost is an important item in the cost estimate used to compensate for unforeseen uncertainties and risks against underestimating budgets for the construction phase. In addition, contingency is directly related to the accuracy of base estimates because it is included in the cost estimate, which is prepared before the start of project execution (Molenaar, 2005). These costs are allocated to anticipate over the lack of information and errors in interpreting the information obtained, giving rise to an uncertainty. This can be one of the risks to be faced in future implementation of a project. Allocation of these costs should be minimized, by making thebest and complete estimateof theuncertainties,or in the case of deficiencies of such information by askingdirectly the project ownersorstakeholders. Its aim is togetvalue forthe right offer. If the contingency allocation is too low, then it may be too rigid and set an unrealistic financial environment, which may result in unsatisfactory performance outcomes (Touran, 2003).

According toMakandPicken(2000), contingencycostis theamountof fundsavailablein reserveto facethe uncertaintiesrelated toconstruction projects. Contingency fee is essential if previous experience related to costs shows that there are unpredictable events that occur and result in increased costs. Therefore,contingencycontractingcostscan beviewed asanestimate ofthe costofthe risksdue touncertainconditionsthat will be facedby the contractorduring theexecutionof the project, whichis a functionof the level ofconfidencethat representsthe level of riskaccepted by thecontractor.

Contingency cost allocation should be minimized, by doing their best to estimate the complete vagueness or lack of information, by asking directly the owner of the project or related parties. Hendrickson(2003)stated thatthe majority ofconstruction budgetsprovide areserve forcontingencycostsorunexpectedcostsincurred duringthe construction. According to Latupeirissa et al. (2007),there is acommon perceptionrelated touncertaintiesandrisksthat have been identifiedby the respondents. Thecommon perceptionis reflectedin the answersof the respondentswhoagreed that contingencycostsarea move preparedin anticipation ofuncertaintyand the risks. A total of 42 respondents (67\%) gave the same answer about contingency costs. According to Latupeirissa et al. (2007), approximately 32respondents $(51.6 \%)$ defined projectcontingencycostsas a waytoanticipate thecostoverruns. Thisresponseimpliesthat the respondentshavenoticedthatnearly everybudgetoverruns andcontingencycostsare providedto coverthecostoverruns.

\section{Conclusion}

The results of this study were obtained 3 factors causing cost overruns, namely Estimated costs (X1), Implementation and working relationships (X2), and the project documents (X3). To anticipate the risks, is required to allocate the cost of contingencies, where the contingency fee is a means to anticipate uncertainty and risk in the implementation of construction project. In addressing risks, contractors often using intuition based on experience and assessment of contractors, contractors must be able to predict the risk what wouldoccur in the future in order to avoid cost overruns during the project implementation.

\section{References}

[1]. Attala, M., and Hegazy, T. (2003). Predicting cost deviation in reconstruction projects: Artificial neural networks versus regression.J. Constr. Eng. Manage, 129(4), 405-411.

[2]. Bhargava, A., Anastasopoulos, P., Labi, S., Sinha, K. C., and Mannering, F. L. (2010). Three-stage least squares analysis of time and cost overruns in construction contracts.J. Constr. Eng. Manage. 136(11), 1207-1218.

[3]. Birnie, J., and Yates, A. (1991). Cost prediction using decision/risk analysis methodologies. Constr. Manage. Econ. 9(2), $171-186$.

[4]. Chan, D. W. N., and Kumaraswamy, M. M. (1997). A comparative study of causes of time overruns in Hong Kong construction projects. Int. J. Proj. Manage. 15(1), 55-63.

[5]. Flyvbjerg, B. (2007a). Policy and planning for large scale-infrastructure projects: Problems, causes, and cures. Environ. Plann. B Plann. Des., 34(1), 578-597.

[6]. Flyvbjerg, B. (2007b). Cost overruns and demand shortfalls in urban rail and other infrastructure, Transp. Plann. Technol, 30(1), 930. 
[7]. Flyvbjerg, B. (2008). "Curbing optimism bias and strategic misrepresentation in planning: Reference class forecasting in practice.Eur. Plann.Stud, 16(1), 3-21.

[8]. Flyvbjerg, B., Holm, M., and Buhl, S. (2002). Underestimating costs in public works projects: Errors or lie?,J. Am. Plann. Assoc,68(3), 279-295.

[9]. Fahirah, F 2005, Causes of Cost Overrun in Building Construction Project in Makassar, Proceedings of the National Seminar on Management of TechnologyI, ISBN: 979-99302-0-0, InstitutTeknologiSepuluhNopember, Surabaya.

[10]. Hester, W. T., Kuprenas, J. A., and Chang, T. C. (1991). Construction changes and change orders: Their magnitude and impact, Source document 66. Construction Industry Institute, Univ. of Texas, Austin, TX.

[11]. Hendrickson, C., Akinci, B., \&Karaesmen, I. (2003). Exploiting motor vehicle information and communications technology for transportation rngineering. Journal of Transportation Engineering, 129, 469

[12]. Ibrahim, B 1995, Planning and Estimate Real of Cost, BumiAksara, Jakarta.

[13]. Ibbs, C. W., and Allen, W. E. (1995). Quantitative impacts of project change, Source document 118. Construction Industry Institute, Univ.of Texas, Austin, TX.

[14]. Iyer, K. C., and Jha, K. N. (2005). Factors affecting cost performance: Evidence from Indian construction projects.Int. J. Project Manage, 23(4), 283-295.

[15]. Iyer, K. C., and Jha, K. N. (2006). Critical factors affecting schedule performance: Evidence from Indian construction projects. $J$. Constr. Eng. Manage. 132(8), 871-881.

[16]. Jahren, C., and Ashe, A. M. (1990). Predictors of cost-overrun rates.J. Constr. Eng. Manage. 116(3), 548-552.

[17]. Jones, L. R., and Euske, K. J. (1991). Strategic misrepresentation in budgeting.Journal of public administration research and theory : J-PART, 1(4), 437-460.

[18]. Kumar, D. (1989). "Developing strategies and philosophies early for successful project implementation. Project Manage. J, 7(3), $164-171$.

[19]. Lovallo, D., and Kahneman, D. (2003). Delusions of success: How optimism undermines executives' decisions. Harvard Bus. Rev, 56-63

[20]. Latupeirissa, EJ 2007, Perceptions of contingency fees contractor in Indonesia: A Survey, Journal of Civil Engineering, 7(3), June 2007: 274-286.

[21]. Love, P. E. D. (2002). Influence of project type and procurement method on rework costs in building construction projects. $J$. Constr. Eng. Manage, 128(1), 18-29.

[22]. Mak, S and Picken, D 2000, Using Risk Analysis to Determine Construction Project Contingencies, Journal of Construction Engineering and Management, 126 (2).

[23]. Mentalini, K, DY 2010, Analysis of the causes of changes in Project Cost In Construction Building in the city of Gianjar, Civil Engineering Faculty at Udayana University, Denpasar.

[24]. Molenaar, K. R. (2005). Programmatic cost risk analysis for highway megaprojects.Journal Construction Engineering Management, 131(3), 343-353.

[25]. Nijkamp, P, and Ubbels, B. (1999). How reliable are estimates of infrastructure costs? A comparative analysis, Faculty of Economics, Business Administration and Econometrics, Free Univ. Amsterdam, the Netherlands.

[26]. Odeck, J. (2004). Cost overruns in road construction: What are their sizes and determinants? Transport Policy, 11(1), 43-53.

[27]. Trost, S. M., and Oberlender, G. D. (2003). Predicting accuracy of early cost estimates using factor analysis and multivariate regression. J. Constr. Eng. Manage, 129(2), 198-204.

[28]. Touran, A. (2003). Probabilistic model for cost contingency. Journal Construction Engineering Management, 129(3), $280-284$.

[29]. Rizal, ZT 1996, Project control by integrating the deviation costs. ITB, Bandung.

[30]. Wattimury, Walangitan, andSibi, M 2015, Identification of factors that cause swelling of overhead costs on development projects in Manado Town Square III, Journal of Static Civil, 3 (4), April 2015 (260-267) ISSN: 2337-6732, Universitas Sam RatuLangi, Manado. 